\title{
LAB-SCALE EXPERIMENTS FOR SOIL CEMENTING THROUGH BIO-CHEMICAL PROCESS
}

\author{
Nguyen Ngoc Tri Huynh ${ }^{12 *}$ \\ Tran Anh Tu², Nguyen Pham Huong Huyen ${ }^{3}$, Nguyen Khanh Son ${ }^{2}$ \\ ${ }^{1}$ Department of Architecture, Tokyo University of Science, Japan \\ ${ }^{2}$ Faculty of Materials Technology, Ho Chi Minh City University of Technology, VNU-HCM, Vietnam, \\ Tel: +84944019686, email: nnthuynh@hcmut.edu.vn \\ ${ }^{3}$ Department of Biotechnology, Ho Chi Minh City University of Food Industry (HUFI), Vietnam
}

Received Date: April 29, 2020; Revised Date: June 4, 2021; Acceptance Date: November 29, 2021

\begin{abstract}
Ureolytic bacteria strains of Bacillus show its ability of calcium carbonate precipitation through metabolic activity. Different studies related to self-healing concrete material were reported associated with the generated calcium carbonate of Bacillus subtilis HU58 metabolism in recent communications. In this paper, recent findings of soil cementing with a combination of such precipitated products were presented. The experiments relied on the lab-scale studies with the use of sand-clay mixture as the controlled soil specimens. Bacillus bacteria and nutrients were mixed to introduce in the sand matrix and then curing in high moisture condition. The composition and morphology of soil specimens were characterized after solidifying by FTIR, XRD, and SEM. Water percolation and mechanical stability for the physicomechanical properties were also tested with the unconventional method. Discussing the relevant results can help to figure out the next experiments in the field of geotechnical engineering. From the perspective of this study, the sustainability factor should be considered to apply this promising technique for soil stabilization and improvement and/or for the formulation of bio-brick as an alternative to sintered clay-based brick. From the perspective of this study, this technique for soil stabilization and improvement and/or for the formulation of bio-brick can be considered a promising sustainable alternative to sintered clay-based brick.
\end{abstract}

Keywords: Bacillus subtilis metabolism, Bio-cementation, Microbially induced $\mathrm{CaCO}_{3}$ precipitation, Soil improvement

\section{Introduction}

The biochemical mechanism of microbial calcium carbonate precipitation or $\mathrm{CaCO}_{3}$ precipitation, called MICP, is based on the combined reaction of carbonate ions $\left(\mathrm{CO}_{3}{ }^{2-}\right)$ derived from some microorganisms' urease enzyme bacteria and calcium ions $\left(\mathrm{Ca}^{2+}\right)$ in the nutrient solution.

As illustrated in Figure 1, certain factors that control such precipitation reactions are the type of bacteria with urease activity, cell concentration, $\mathrm{pH}$ of the surrounding environments, temperature, reaction period, and especially nutrient source for microorganism growth. The appropriate type of bacteria consists of its essential urease production and its ability to withstand harsh environments for long periods. Concerning previous studies in literature, Bacillus strains are now the most commonly used for MICP, differentiated by various application orientations. For example, Bacillus cohnii [1], Bacillus pasteurii [2], Bacillus pseudofirmus [3], and Bacillus subtilis [4-7]. The source of nutrients should be investigated from both chemical components (urea and calcium concentrations) and costsaving. Microorganisms use urea as a source of nitrogen for the urea hydrolysis process. Besides, precipitation reaction carries out on the cellular membrane with a high concentration of calcium source. Also, the high cost of organic nutrient sources necessary for bacterial growth now constitutes one of the most critical impacts of the larger MICP application scale. 


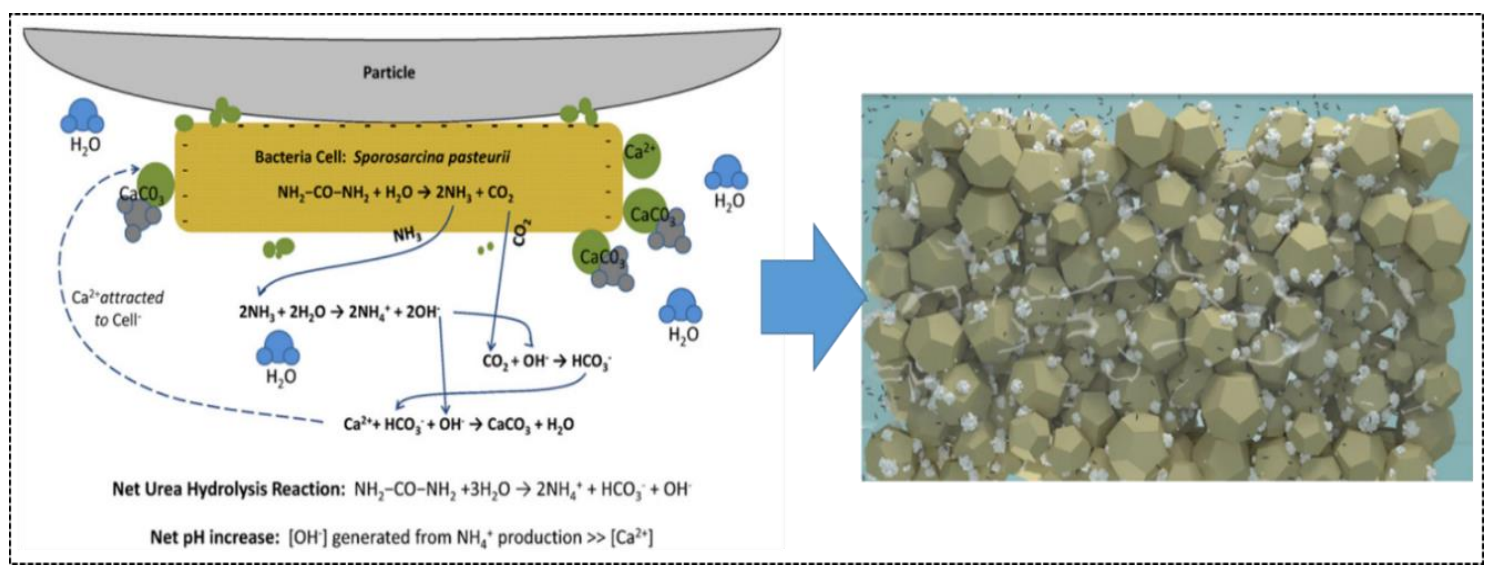

Figure 1. Illustration of MICP mechanism of ureolytic bacteria (left) [8] and schematic model of soil grain cementing with precipitated $\mathrm{CaCO}_{3}$ product due to MICP (right) [9]

Considering the generated calcium carbonate products, they could be identified with different morphological forms such as calcite, aragonite, and vaterite. As stated in the natural condition, those minerals show their high performance in stiffness and durability under severe conditions.

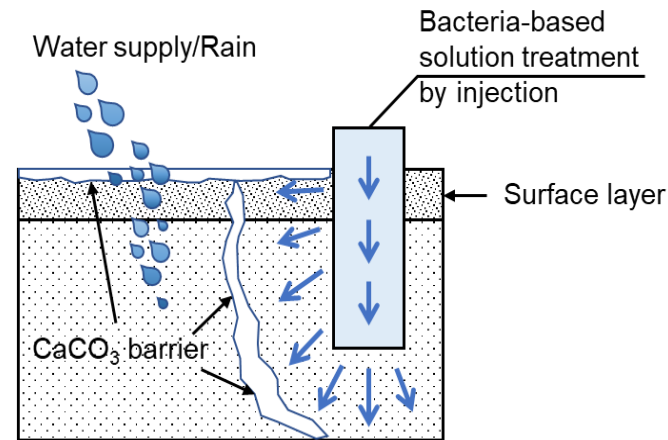

- High rate of $\mathrm{CaCO}_{3}$ forming lead to $\mathrm{CaCO}_{3}$ barrier, slow down/stop the water/mass transport

- Difficlut homogeneous MICP for all volume

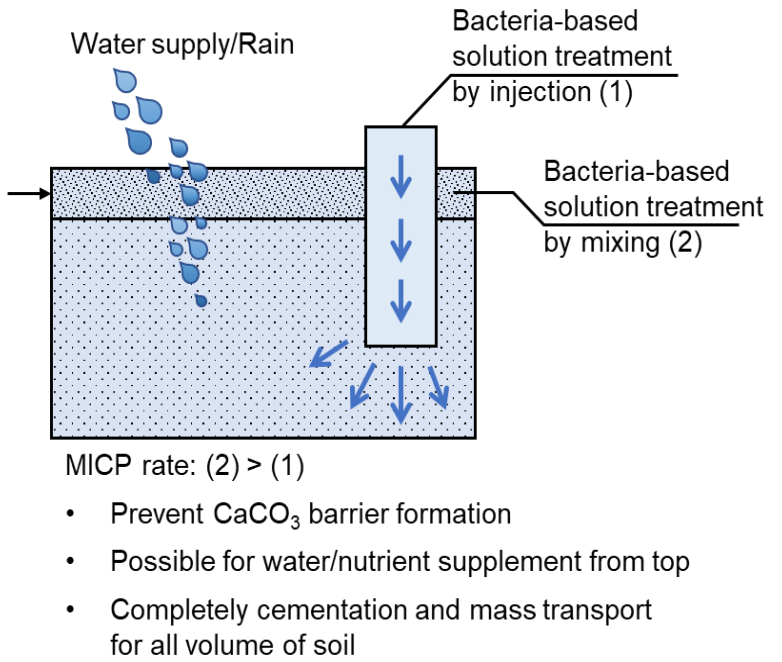

Figure 2. Two strategies of the bio-grouting method for soil improvement and stabilization: (left) injection technique (right) surficial flooding technique [16-19]

Recently, a promising perspective of bio-inspired geotechnical engineering or soil bio-cementation aims to use MICP for soil improvement and stabilization. Binding soil particles with precipitated products of $\mathrm{CaCO}_{3}$ is recommended as an alternative solution with sustainability comparing to the conventional binder of Portland cement. In the history of the application of biological processes, one of the first explicit discussions was presented by Mitchell and Santamarina [10] with bacteria referred to as colloids form, at least of effective diameter around $10 \mu \mathrm{m}[11,12]$. As reported by some authors [13-15], both physiomechanical properties of reinforced soil were improved after such treatment and waterproofing capacity of soil cementing matrix could help prevent the considerable risk of water softening or liquefaction of weak soil. 
Until now, a common soil improvement technique is to inject synthetic man-made materials using a variety of chemical, jetting and permeation grouting techniques. However, these approaches create environmental concerns because most of chemicals are either toxic or hazardous. This situation requires new, sustainable methods for the densification of the losing sand in land reclamation and improvement in mechanical properties of soil with minimum negative impacts on the living environment. According to [20], an effective technique of bacteria intrusion must consider the effect of solute transport through porous media of soil matrix due to combined phenomena of advection, diffusion, dispersion, and absorption. The authors have published the principle in which fine-grained crystal position of calcium carbonate could be firstly created due to the high local concentrations of calcium and carbonate ions. The subsequent stages of crystal growth may occur from these crystal nuclei depending on various factors such as bacterial activity, nutrition, and boundary constraint. The following Figure 2 schematizes the two most common soil cementing techniques by using bacteria solution or biogrouting method, that could be applied through surficial flooding technique or injection technique with single or multiple cycles depending on construction conditions. Despite the practical benefits of the application, they still have some limitations, and for example, they require a large number of bio-grout injection pipes to avoid the heterogeneous spatial structure of soil after such treatment. The last means depending on the near or far from the nozzle hole, the soil is more or less compact with generated calcium carbonate products. Besides that, local condensation of those minerals near the nozzle hole as the clogging phenomenon can prevent bacterial solution diffusion. Moreover, soil ground with natural diversity and non-uniform distribution might also affect the treatment technique's overall performance.

In the following paragraphs, experiments with the first framework in laboratory conditions will be presented. At the materials' scale, the SEM method was used to analyze precipitated products due to bacterial metabolic activity and bonding conditions between sand particles of controlled specimens. Materials composition and mineralogy of soil specimens after solidifying were also characterized by using XRD and FTIR analysis method. At the scale of soil specimens, the water percolation test was carried out through specimens of the sand column prepared in a syringe barrel $(60 \mathrm{ml})$. Besides that, gross deformation (or settlement) of cubic specimens of the soil-sand mixture were tested to identify the shaping capacity by itself. This study's perspective was discussed in the results section, focusing on this eco-friendly technique's practical application.

\section{Materials and Experimental Set-up}

\section{Materials}

Ureolytic bacteria Bacillus subtilis (HU58) was used with the initial concentration of 109 $\mathrm{CFU} / \mathrm{g}$. Bacterial spores were manufactured and commercialized under license from Royal Holloway College of the University of London (RHUL) for frequent food industry usage. Commercial urea is usually used as chemical fertilizer in the agriculture sector, and calcium chloride as the laboratory's chemical agents were used to formulate the bacteria cultivation solution. Coarse grain size sand was prepared for the following solidification test in the plastic syringe from a natural river sand source. After washing, the grain size distribution was analyzed according to size with two standard sieves: $1.25 \mathrm{~mm}$ (retain) and $2.50 \mathrm{~mm}$ (pass).

For sampling cubic specimens in mold $5 \times 5 \times 5 \mathrm{~cm}^{3}$, raw kaolin in the ceramic industry was used as a supporting component (weight ratio coarse sand: kaolin =9: 1,8:2). The natural sticky property of kaolin while in contact with water could help us cement together the mixture's original loose sand particles. 


\section{Experimental Set-up in Laboratory and Analysis}

The syringe solidification test was set up as an unconventional test method for soil column cementing. First, the possibility of binding sand particles was investigated with the bacterial precipitation solution. Second, after analyzing the bonding material of sand interparticle's prepared specimens, the main factor that affects the solidification process was also clarified. As shown in Figure 3, barrels of the plastic syringe were used as sand containers in this test. Each barrel tube $(60 \mathrm{ml}$ volume, outlet diameter $=4.5 \mathrm{~mm})$ contained 50 grams of a mixture of coarse sand, bacteria, and nutrients. The slight compression was applied with the syringe plunger. With the milliliter-scale help on the barrel tube, the same level of materials could be maintained under visual observation for each test. Three mixtures of bacteria, $\mathrm{CaCl}_{2} \cdot \mathrm{H}_{2} \mathrm{O}$, and urea, were prepared with the weight ratio of bacteria: sand $=1: 99,2: 98$, and 3:97. $20 \mathrm{ml}$ of water was then introduced from the top of the syringe and flowed through the sand column below due to gravity (Figure 3a). As there is a relationship, the tighter the sand column was, the less water flow was measured. The water flow results were recorded daily and linked them to the densification condition of the sand specimen in the syringe barrel. Since water has been prevented from diffusing through the matrix of solidified sand, a steel cubic with a weight of $993.6 \mathrm{~g}$ was used (Figure $3 \mathrm{~b}$ ) to accelerate the water flow under static pressure.

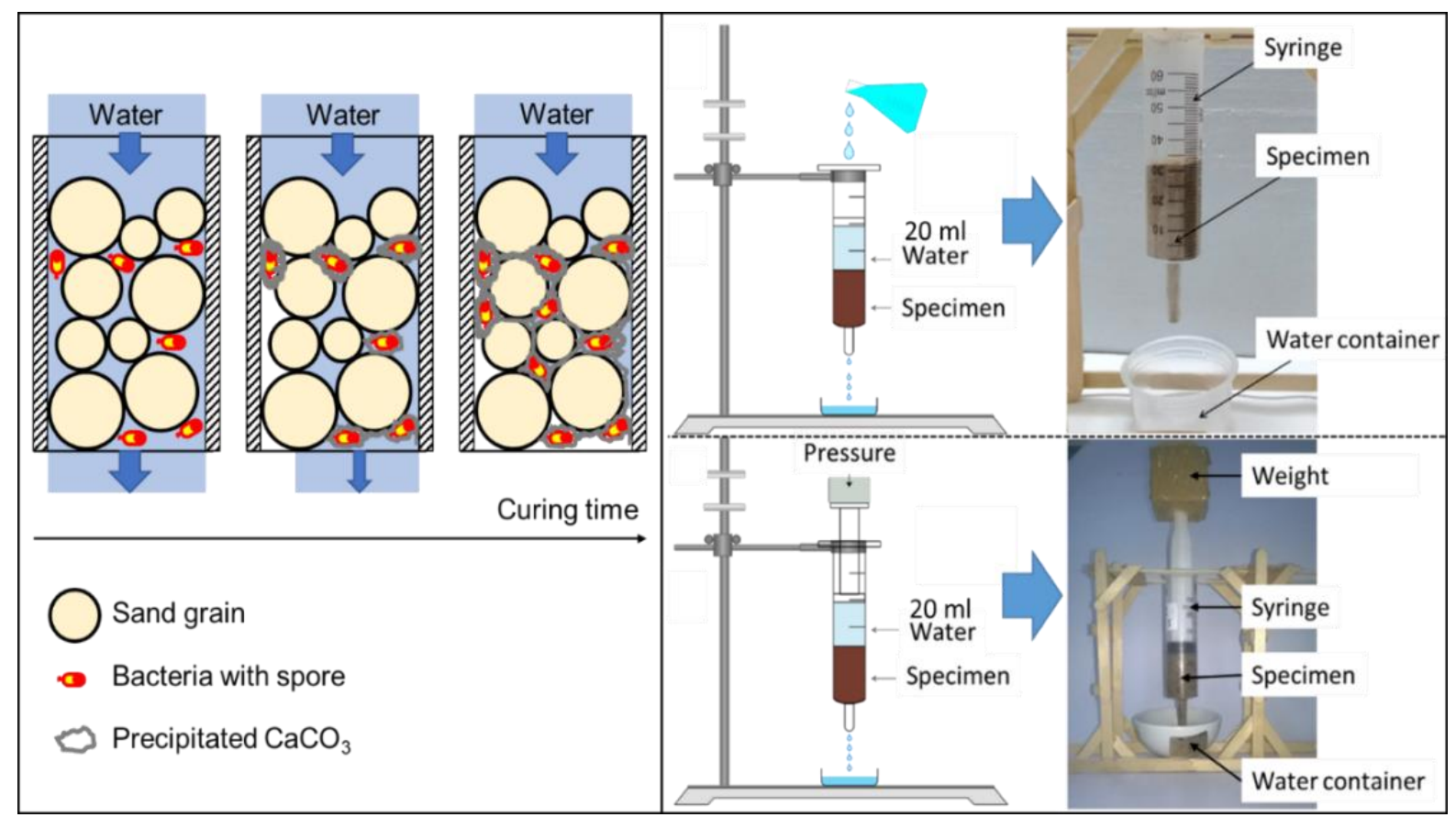

(a)

(b)

Figure 3. Simulated water percolation through sand column (a) and implementation of syringe solidification test in laboratory (b)

To set-up the test of soil cementing in cubic mold, the sand matrix's physicalmechanical resistance treated by the bacterial solution were studied. The above coarse sand and clay, were mixed with bacteria, nutrients, and water in the planetary mixer and placed in cubic mold $5 \times 5 \times 5 \mathrm{~cm}^{3}$ for sampling. Three mixtures were prepared with the clay component as the sand replacement, respectively 0,10 , and $20 \%$ by weight. The suitable amount of water was adjusted to mix and sample as $6 \mathrm{~g}$ per $100 \mathrm{~g}$ of sand-clay mixture. After that, all soil specimens were kept in the mold and cured under the saturated relative humidity condition at room 
temperature. The unconfined compression testing of the settlement of soil specimens was done after 3 and 14 days of curing time with the help of a universal compression machine (load rate $0,001 \mathrm{kN} / \mathrm{s}$ for a loading period of $45 \mathrm{~s}$ ).

For material analysis, Fourier-transform infrared spectroscopy (FTIR), X-ray diffraction (XRD), and scanning electron microscopy (SEM) were used for phase detection and morphology identification. XRD analysis was conducted by using a diffractometer (D8 ADVANCE - Brucker) with the wavelength of $\mathrm{Cu} \mathrm{K \alpha}$ X-rays was $1.5418 \AA$ A. SEM/EDS was carried out by using the scanning electron microscope (SEM-FE S4800 Hitachi). The FTIR analysis with FTIR - 8400S - SHIMADZU was adopted in the range of wavelength from 400 $\mathrm{cm}^{-1}$ to $4000 \mathrm{~cm}^{-1}$.

\section{Results}

\section{Materials analysis and microstructure of biocemented sand}

Figure 4a shows SEM images taken with magnifications from four sand specimens after the syringe solidification test distinguished by bacterial content, respectively $0,1,2,3 \mathrm{wt} \%$ of coarse sand. For controlled specimens ( $0 \mathrm{wt} \%$ bacteria), it could be easy to recognize the coarse grain of sand lying separately from each other (Figure 4 - left). In the microstructure, they existed many pore positions (black color) due to the random arrangement of coarse particle. Friction between those particles seems to be high and be responsible for the collapse of the sand column model in its natural state. For the three remaining specimens (1, 2, $3 \mathrm{wt} \%$ bacteria), the fine-grain crystal position could be identified as highlighted in the cementing layer on the rough surface of sand particles. In a few sections, microbial footprints could be recorded (yellow dashline cycle in Figure 4). At the higher magnification $(20.0 \mathrm{kX})$, they appeared a heterogeneous mix of clear acicular rod-shaped crystals as in aragonite and rhombohedral crystals as in calcite. Compared to the loose state of controlled sand specimens, solidified sand's microstructure showed less porous and more homogenous in general. Also, SEM images show that precipitated products exhibited in different forms and situations such as resting on sand grains or solid mass between grains, which effectively providing bonding.
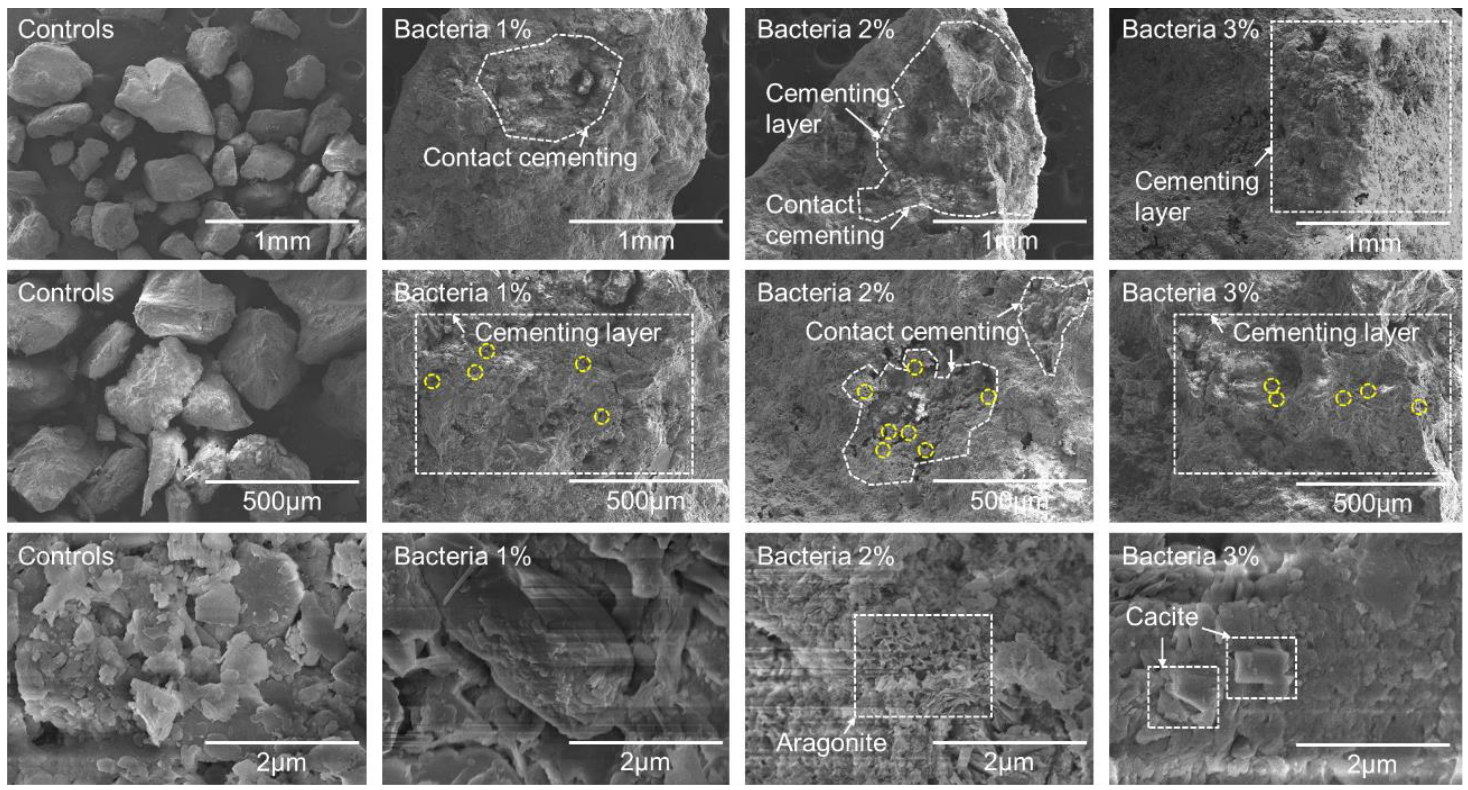

Figure 4. SEM images of the analyzed sandy specimens after syringe solidification test 
Besides that, as confirmed in the XRD pattern (Figure 5a-left), the presence of both calcite and aragonite could be detected behind quartz as the major mineral phases. However, when focusing on the intensity of quartz, gradually decreasing can be observed at the same time (Figure 5a-right) with the presence of other carbonate phase formations. This result suggests that new precipitated materials connected sand grains under bacterial activities. Note that the weak peaks of some crystalline carbonate in the XRD pattern of precipitated products after the biomineralization process could be assumed to the presence of amorphous phases. However, those major peaks' increasing intensity seemed to the induced precipitated products covered the sand grains. Also, the FTIR spectrum (Figure 5b) revealed absorption peaks at $875,1420 \mathrm{~cm}^{-1}$ peculiar to calcite and $856,1475 \mathrm{~cm}^{-1}$ for aragonite. In general, the biological mineral $\mathrm{CaCO}_{3}$ is more resistant to solubility than the one formed by inorganic precipitation. This phenomenon can play a vital role in making the bio-cementation of loose sand particles more durable over time than chemical agents.

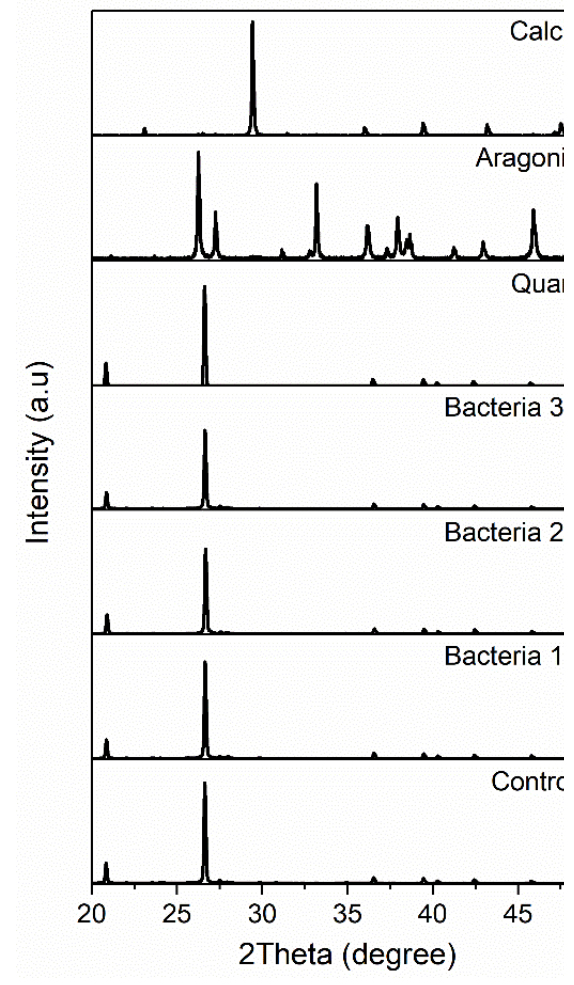

(a)

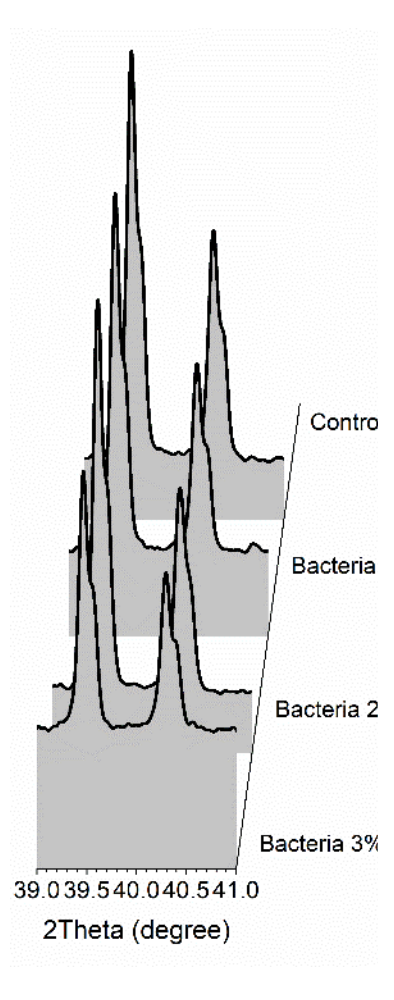

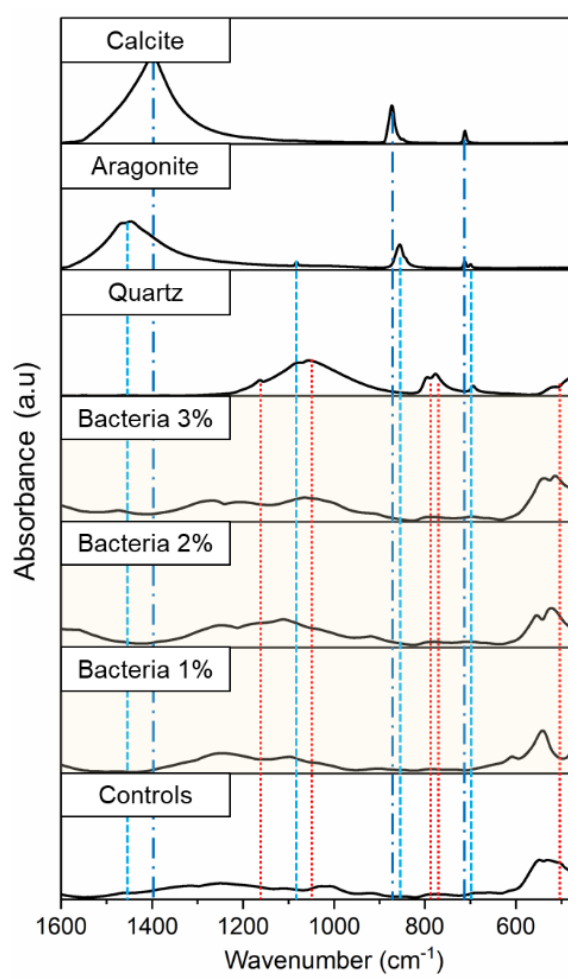

(b)

Figure 5. (a) XRD patterns. Reference XRD standard pattern PDF code: 00-005-0586 for calcite; 00-041-1475 for aragonite; and 00-046-1045 for quartz. (b) FTIR spectrum of the analyzed sandy specimens after syringe solidification test

\section{Water percolation test through sand column}

Figure 6 summarizes the measured values of water absorption through sand column specimens over different curing periods. As shown in Figure 7, the sand column with a loose state in controlled specimens allowed water to flow smoothly. Also, there was only a small fluctuation regarding the measured values over 28 days as evaluation periods. Moreover, as a consequence of the biomineralization process, Figure 7-left showed the sand column's bonding state in the mixture containing bacteria and nutrients. Coarse sand particles seemed to be condensing from one to another, and this phenomenon developed over time until the solidification of the sand 
column. After one day, the rapid decrease of water absorption results could be identified for both three tests with bacteria using as an admixture (less than $3 \mathrm{wt} \%$ ). Over 28 days of curing time, the more the sand grains were bonded together, the less water amount could be absorbed through the sand column's height.

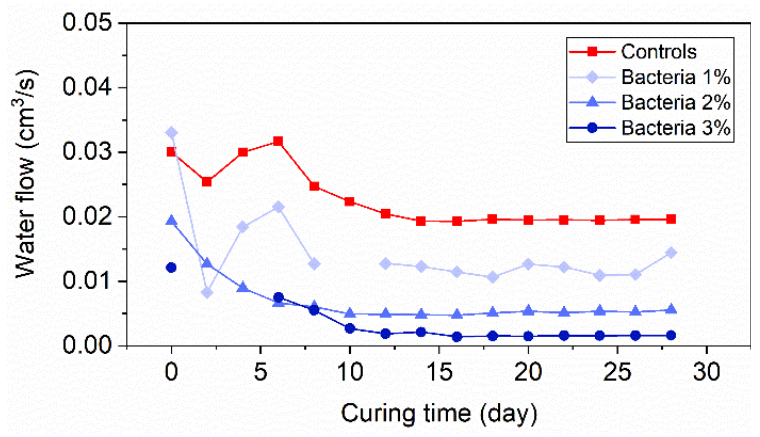

(a)

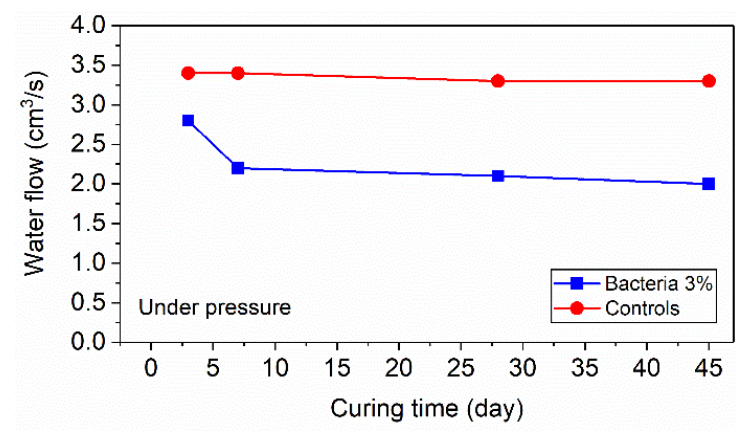

(b)

Figure 6. (a) Measurement of water absorption through the sand column after the syringe solidification test without pressure. (b) Test result under pressure

From the viewpoint of material microstructure, precipitated $\mathrm{CaCO}_{3}$ due to bacteria metabolism could be considered a filling component generated inside interparticle pores position. It is also highlighted that all three specimens showed the same stable stage after obtaining the peak value in 14 days. Figure 6 a revealed a slightly decreasing amount of water absorption for the period from 14 to 28 days. A higher water flow rate of up to $3.45 \mathrm{~cm}^{3} / \mathrm{s}$ compared to $0.03 \mathrm{~cm}^{3} / \mathrm{s}$ could be seen when accelerating water flow under static pressure. Figure $6 \mathrm{~b}$ showed the comparison between controlled specimens without bacteria and those of bacterial specimens. With regards to the same experimental condition, the rate of water flow is around 1.5 times higher for the case of the solidified sand column. The formation of $\mathrm{CaCO}_{3}$ could entrap the voids of the sand grains and hence prevent the fluid flow. However, this phenomenon might also cause the cut of the necessary water that circulated and fed the bacteria in the bottom zones. Dead bacterial cells could not maintain the biomineralization and then lead to losing a small part of sand grains in the discharge water flow. Besides, the water flow could have resulted in the flushing out of the bacteria's new-forming spore. Since no new bacteria was supplied, the metabolic ability in the sand matrix was significantly reduced.

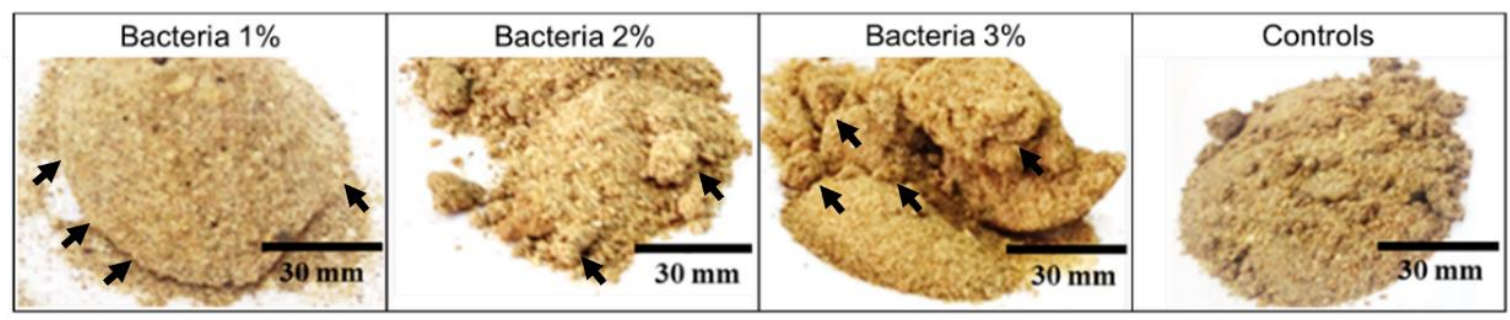

Figure 7. Illustration of grain bonding state after unloading from the syringe barrel (arrows indicate where grain bonding occur)

It is essential to note the appropriate ratio between bacterial cells and nutrients because spore formation can cause the "pause" phase of $\mathrm{CaCO}_{3}$ precipitation. The highest mineralization can occur when bacteria are in the active stage and are exposed to sufficient nutrients. In the 
spore form, which is the dormant stage, bacteria can save energy and maintain their longevity for a long time; however, it may result in discontinuation or delay of mineral precipitation. However, the flushing and damages by high-pressure water flow to precipitated products among sand grains may expose endospores that germinate and resume the mineralization, causing an increase of cementing effect.

\section{Gross deformation of soil-sand cementing specimens}

It can be observed that controlled specimens without clay could not hold the cubic shape after removing mold, as illustrated in Figure 8a (R0). Also, it is easy to observe sand specimens with clay and bacteria under the microscope precipitated $\mathrm{CaCO}_{3}$ around the grain surface (white layer) that constituted a mineral glue for sand cementing (Figure 8b). The size of voids among sand grains is a significant factor in bacterial biomineralization to result in effective occlusion and bio-cementation. With the average size of crystals produced in vitro process were around $2.5 \mu \mathrm{m}$ [21] (by light microscopic analysis and TEM), space around 100 times greater could be adequately filled by applying bacterial cells and nutrients. The crystal size and morphology of precipitated products could be influenced by various factors, including the nucleus and local supersaturation density. Perhaps, different environmental factors can contribute to the crystals forming, including combinations in bacterial biofilms. Moreover, in Figure 8a, it can be reported that cubic specimens of sand-clay mixture after removing them from the mold. The last means that with both clay component and precipitated $\mathrm{CaCO}_{3}$ due to bio-cementation, initial loose sand showed its ability to shape.

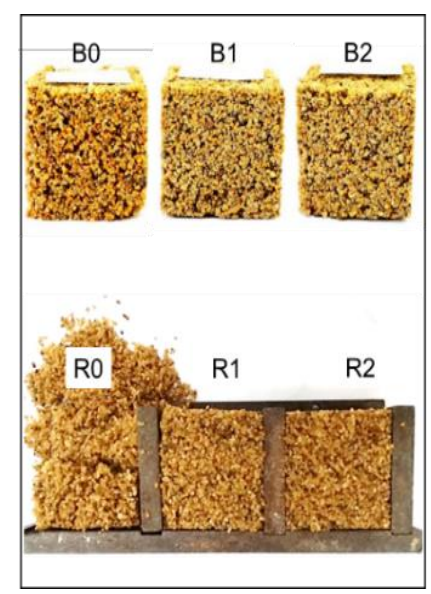

(a)

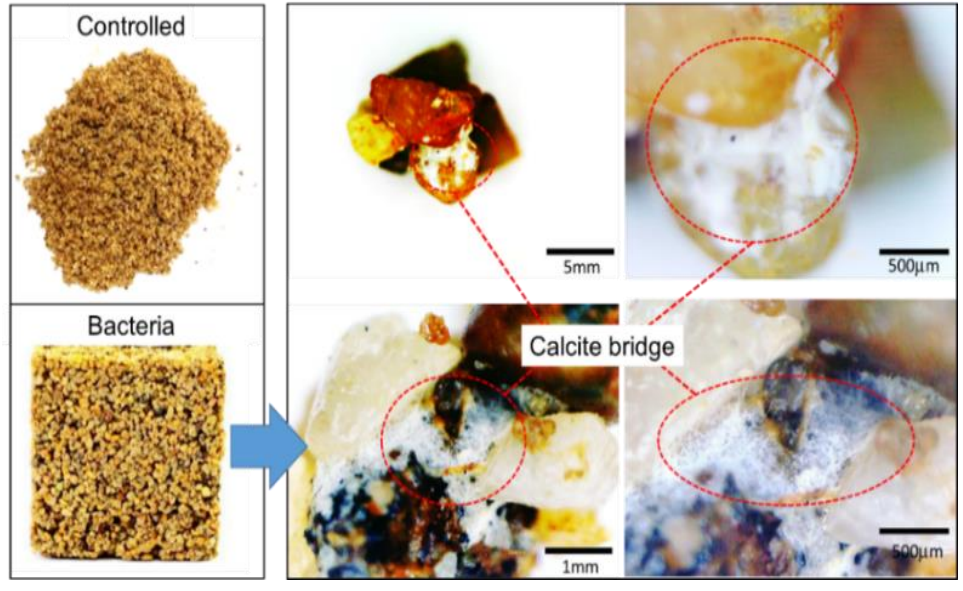

(b)

Figure 8. (a) Sampling soil-sand mixture in cubic mold. (b) Microscopic observation of $\mathrm{CaCO}_{3}$ bridge due to $\mathrm{MICP}$

Figure 9 reveals the obtained results of gross deformation (settlement) tested on a series of cubic specimens. Cube series named B1, B2, and R1, R2 were corresponding to 10 and $20 \%$ of clay content, and B0, R0 were corresponding to controlled specimens (without clay). It is highlighted that the most deformable cube was almost $100 \%$ associated with the controlled sand specimen. Compared to the controlled cube, it could be seen that the deformation ratio of the two remaining cube series (B2 and R2, B1 and R1) was less important. Furthermore, those of B2 and R2 were higher than those of B1 and R1. Therefore, it could contribute to firstly its shaping ability and secondly to its mechanical stability due to the presence of $\mathrm{CaCO}_{3}$ bridge in the structure of cubic specimens of sand. 

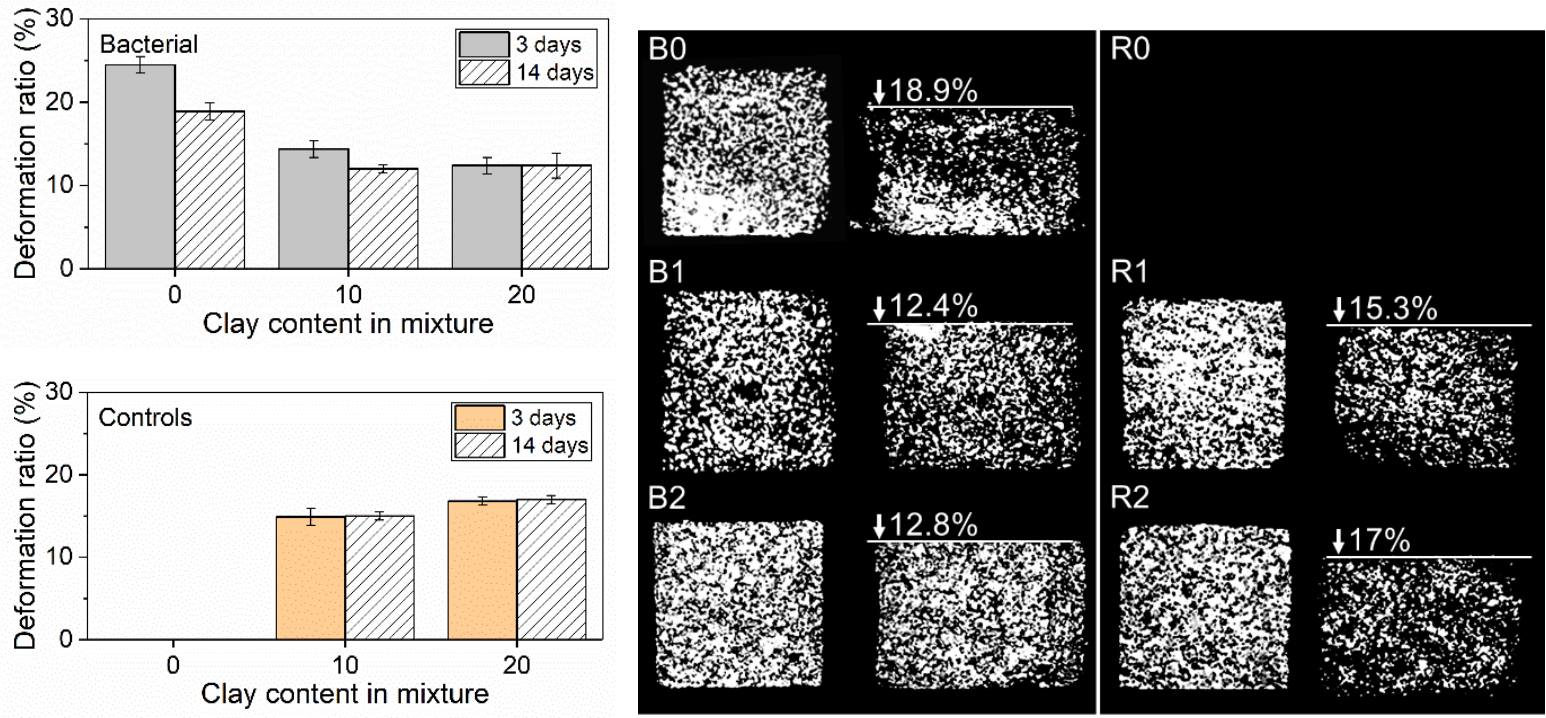

(a)

(b)

Figure 9. (a) Vertical deformation of cubic specimens under unconfined compression testing.

(b) Comparison of estimated deformation ratio

\section{Conclusions}

To conclude, the experimental studies were based on the laboratory-scale using Bacillus subtilis (HU58) for soil cementing. Even though almost experiments relied on small soil-liked specimens and unconventional approaches regarding the standardized testing method in geotechnical engineering, the significant results were obtained to expand the current studies at the next phase. Bacteria can be mixed directly into the soil with a small amount of less than $5 \%$ but reveal its metabolic activity for $\mathrm{CaCO}_{3}$ precipitation. Results of material characterization by SEM, XRD, and FTIR revealed the precipitated $\mathrm{CaCO}_{3}$ as a mixture of calcite and aragonite. Such generated mineral phase, in its turn, plays the role of cementing sand grains and filling components of the microstructure. However, in the next study, Raman spectroscopy should combine FTIR to discern between potential polymorphs.

Both results of water absorption and specimens' deformation rate also confirmed the benefit of precipitated $\mathrm{CaO}_{3}$ presenting in the sand matrix, prevented the water penetration through the sand column, and reinforce the sandy stability for sampling. Sporulating organisms as Bacillus subtilis HU58 can naturally produce spores, particularly under harsh environmental conditions or lack of suitable nutrients, and so can remain to survive for a long time. Therefore, resupplying additional chemicals/nutrients when required, entirely possible to restart or accelerate the MICP process.

Although many challenges need to be taken into account to scale up this promising ecofriendly technique for soil improvement and bio-brick formulation, the results of this study suggest the protocol, including pre-mixed bacteria, can be used as an additional technique with the onephase injection or multiple-phase injection to enhance the MICP capacity and effectiveness. Also, it is necessary to optimize the technical conditions like $\mathrm{pH}$, temperature, soil, nutrients concentration for bacterial growth, and its activity before up-scale to get homogeneous distribution in the large-size soil samples. 


\section{Acknowledgements}

This research was supported by the International Foundation for Science, Stockholm, Sweden, through a grant to Nguyen Pham Huong Huyen.

\section{References}

[1] H.M. Jonkers, "Self-healing concrete: A biological approach," Self-Healing Materials, Vol. 100, pp. 195-204, 2007.

[2] S.K. Ramachandran, V. Ramakrishnan, and S.S. Bang, "Remediation of concrete using micro-organisms," Materials Journal, Vol. 98, No. 1, pp. 3-9, 2001.

[3] H.M. Jonkers, and E. Schlangen, "Development of a bacteria-based self-healing concrete," Tailor Made Concrete Structures, Vol. 1, pp. 425-430, 2008.

[4] D. Gardner, R. Lark, T. Jefferson, and R. Davies, "A survey on problems encountered in current concrete construction and the potential benefits of self-healing cementitious materials," Case Studies in Construction Materials, Vol. 8, pp. 238-247, 2018.

[5] N.N.T. Huynh, N.Q. Nhu, and N.K. Son, "Developing the solution of microbially induced $\mathrm{CaCO} 3$ precipitation coating for cement concrete," Paper presented at The 14th International Conference on Concrete Engineering and Technology, Kuala Lumpur, Malaysia, 2018, doi: 10.1088/1757-899X/431/6/062006

[6] N.N.T. Huynh, K. Imamoto, and C. Kiyohara, "A study on biomineralization using bacillus subtilis natto for repeatability of self-healing concrete and strength improvement," Journal of Advanced Concrete Technology, Vol. 17, No. 12, pp. 700-714, 2019.

[7] N.N.T. Huynh, N. M. Phuong, N.P.A. Toan, and N.K. Son, "Bacillus subtilis HU58 immobilized in micropores of diatomite for using in self-healing concrete," Procedia Engineering., Vol. 171, pp. 598-605, 2017.

[8] J.T. DeJong, B.M. Mortensen, B.C. Martinez, and D.C. Nelson, "Bio-mediated soil improvement," Ecological Engineering, Vol. 36, No. 2, pp. 197-210, 2010.

[9] D. Terzis, and L. Laloui, "A decade of progress and turning points in the understanding of bio-improved soils: A review," Geomechanics for Energy and the Environment, Vol. 19, pp. 100116, 2019.

[10] J.K. Mitchell, and J.C. Santamarina, "Biological considerations in geotechnical engineering," Journal of Geotechnical and Geoenvironmental Engineering, Vol. 131, No. 10, pp. 1222-1233, 2005.

[11] T.I. Mote, and J. N. Dismuke, "Screening-level liquefaction hazard maps for Australia," Paper presented at Australian Earthquake Engineering Society 2011 Conference, pp. 18-20, 2011.

[12] M.B. De Groot, and P. Meijers, "Liquefaction of trench fill around a pipeline in the seabed," Acta Geotechnica, pp. 1333-1344, 1992.

[13] W. De Muynck, K. Cox, N. De Belie, and W. Verstraete, "Bacterial carbonate precipitation as an alternative surface treatment for concrete," Construction and Building Materials, Vol. 22, No. 5, pp. 875-885, 2008.

[14] W. De Muynck, N. De Belie, and W. Verstraete, "Microbial carbonate precipitation in construction materials: a review," Ecological Engineering, Vol. 36, No. 2, pp. 118-136, 2010.

[15] J.K. Mitchell, and J.C. Santamarina, "Biological considerations in geotechnical engineering," Journal of Geotechnical and Geoenvironmental Engineering, Vol. 131, No. 10, pp. 1222-1233, 2005.

[16] A. Al Qabany, and K. Soga, "Effect of chemical treatment used in MICP on engineering properties of cemented soils," Géotechnique, Vol. 63, No. 4, pp. 331, 2013. 
[17] B.C. Chittoori, A. Pathak, M. Burbank, and M.T. Islam, "Application of bio-stimulated calcite precipitation to stabilize expansive soils: Field trials," In: E. Kavazanjian, Jr., J.P. Hambleton, R. Makhnenko, and A.S. Budge, eds., Geo-Congress 2020: Biogeotechnics, American Society of Civil Engineers, Minneapolis, Minnesota, United States, pp. 111-120, 2020.

[18] L. Cheng, and R. Cord-Ruwisch, "Upscaling effects of soil improvement by microbially induced calcite precipitation by surface percolation," Geomicrobiology Journal, Vol. 31, No. 5, pp. 396-406, 2014.

[19] C.S. Tang, L.Y. Yin, N.J. Jiang, C. Zhu, H. Zeng, H. Li, and B. Shi, "Factors affecting the performance of microbial-induced carbonate precipitation (MICP) treated soil: A review," Environmental Earth Sciences, Vol. 79, No. 5, pp. 1-23, 2020.

[20] S.A. Bradford, S.R. Yates, M. Bettahar, and J. Simunek, "Physical factors affecting the transport and fate of colloids in saturated porous media," Water Resources Research, Vol. 38, No. 12, pp. 63-1-63-12, 2002.

[21] N.N.T. Huynh, N.K. Son, N.P.A. Toan, and L.T.D. Hanh, “A quantitative study of calcium carbonate precipitation by using Bacillus subtilis HU58 for self-healing concrete," Paper presented at The 23rd Regional Symposium on Chemical Engineering (RSCE2016), Vung Tau city, Vietnam, 2016. 